\title{
Analysis of Dictogloss Tasks using Bloom's Digital Taxonomy based on Digitalized Collaborative Work Youngshin $\operatorname{Lim}^{\dagger}$
}

Kongju National University

\begin{abstract}
Associated with Web 2.0 pedagogy, this study aimed to investigate how learners' cognitive skills can be processed in dictogloss in terms of Bloom's digital taxonomy. Sixty-four university students participated in the study with three different types of dictogloss. The overall result of this study demonstrates that dictogloss stimulates lower- and higher-order thinking skills. Specifically, the study finds two crucial points to develop a well-balanced cognitive domain: First, dictogloss enables learners to utilize diverse digital learning actions in digitalized collaborative learning contexts, such as uploading, collaborating, and networking. Second, different modes of online learning delivery (i.e., synchronous and asynchronous modes) promote different levels of the thinking skills applied in the learning process. Based on these findings, the crucial implication could be drawn that dictogloss could stimulate and improve learners' various levels of cognitive process when it is accompanied by a synchronous learning module owing to its immediate interaction in a digitalized collaborative work.
\end{abstract}

Keywords: dictogloss, Bloom's digital taxonomy, cognitive process, digitalized collaborative work, synchronous learning module

\section{Introduction}

In the digital era, technology has transformed the educational paradigm as it affects various aspects. For instance, it changes the way to access knowledge, interact with learning materials and peers, and perform learning tasks by using various online learning platforms (e.g. Google Classroom, Padlet, and Zoom) and online learning tools (e.g. discussion board, blog, video conferencing, chatrooms, and instant messaging). Due to the flexible accessibility to information and learning materials, learners can easily engage in higher-order thinking and creative learning. It could

\footnotetext{
† Corresponding author: 1y224@kongju.ac.kr
} 
be possible to expand the range of utilizing knowledge with various learning tasks and activities that stimulate learners' awareness of their learning (Diaz, 2013). That is, language learners could creatively perform tasks by using web-based learning tools which also could develop diverse cognitive domains.

Given that the learning paradigm has been shifted into technology based learning, the cognitive learning process and its relevant sub-categories have been revised to Bloom's digital taxonomy (Hereafter BDT) (Churches, 2008). This modified framework suggests how learning objectives and activities could be represented concerning features of the digital cognitive learning process. It specifically defines the terms of learning behaviours, actions, and their relevant learning activities based on the use of technology. This renovative framework deals with cognitive elements concerning learning methods and tooling for education which are utilized in a digitalized learning context.

In terms of digitalized learning contexts, in which the learning process is carried out by using technology-based learning modalities and tools, Zeng (2017) and Yilmaz (2011) report that dictogloss is an effective learning task to develop language use at discourse level. It reveals that dictogloss is more effective for language use than other learning tasks (i.e. jigsaw task) when it is employed in synchronous learning. Concerning communicative interactions during cooperative reconstructing process in dictogloss, learners could flexibly utilize the contextual and conditional knowledge to perform cognitive tasks, which are relevant to metacognitive knowledge in Bloom's revised taxonomy (Anderson \& Krathwohl, 2001; Jacob \& Small, 2003; Swain, 2006). This learning method has been also highly recognized in EFL language classes because it has various positive effects in collaborative learning contexts. One of the effects is developing learners' thinking skills in the process of reconstruction. They can analyze the rewritten text compared to the original one as well as raise questions, respond to disagreement, learn from others' ideas and elaborate on the ideas in the process of collaborative learning. It also offers learners opportunities to develop discourse competence while they communicate with members of a group to negotiate meanings. In other aspects, integrative language learning is facilitated in dictogloss as it could combine language functions in various manners (e.g. listening skills and writing skills) (Oh \& Min, 2011).

Although there have been a number of studies conducted to investigate the effects of dictogloss to promote language skills (Baek \& Lee, 2012; Lee, 2011; Park, 2013), few studies analyze dictogloss in the aspect of specified cognitive framework. Hence, concerning the multifaceted characteristics of dictogloss in language learning, the 
present study will investigate how different types of dictogloss tasks apply in digitalized collaborative learning context based on Bloom's digitalized taxonomy with a couple of research questions presented as follows.

1. How do learners perform dictogloss variants in different collaborative learning contexts using web-based learning platforms (i.e. synchronous or asynchronous learning mode)?

2. Concerning cognitive domain, which taxonomic elements of Bloom's digital taxonomy are utilized for each dictogloss variant?

\section{Theoretical Backgrounds}

\subsection{Bloom's digital taxonomy}

This framework is a revised version that incorporates digital technology to each level of Bloom's Revised taxonomy. Since technology has become more ingrained and essential part of learning, the process of learning has been supplemented with digital verbs or behaviours such as blogging, remixing, or programming. In addition, this revised version further promotes 21st-century essential skills, such as collaboration, communication, creativity, and critical thinking. This is because the unique features of digital tools are flexible and accessible to transform and expand the process of learning.

In Table 1, two types of refined Bloom's taxonomy are comparatively presented, which are Bloom's revised taxonomy proposed by Anderson and Krathwohl (2001) and Bloom's digital taxonomy developed by Churches (2008). Bloom's revised taxonomy suggests six levels of the cognitive domain which are arranged in a hierarchical order from lower-order thinking skills to higher-order thinking skills according to the degree of cognitive complexity. That is, each level linked to the previous lower level is a prerequisite to develop a higher cognitive domain (Anderson \& Krathwohl, 2001). On the other hand, Churches' digital taxonomy takes the identical cognitive categories of Bloom's revised taxonomy but further defines learning verbs in terms of digital technologies and digital cognitive objectives. He also states that the digital taxonomy can explain the methods and digital tools needed for conceptual understanding as well as learning progress upon different cognitive levels (Churches, 2008). 
Table 1. Comparative frameworks of modified Bloom's taxonomy

\begin{tabular}{|c|c|c|c|c|c|}
\hline \multicolumn{6}{|c|}{ Bloom's revised taxonomy } \\
\hline Remembering & Understanding & Applying & Analyzing & Evaluating & Creating \\
\hline $\begin{array}{l}\text { listing } \\
\text { recognizing } \\
\text { recalling } \\
\text { identifying }\end{array}$ & $\begin{array}{l}\text { interpreting } \\
\text { exemplifying } \\
\text { classifying } \\
\text { summarizing } \\
\text { inferring } \\
\text { comparing } \\
\text { explaining }\end{array}$ & $\begin{array}{c}\text { responding } \\
\text { providing } \\
\text { executing } \\
\text { implementing }\end{array}$ & $\begin{array}{l}\text { differentiating } \\
\text { selecting } \\
\text { organizing } \\
\text { integrating } \\
\text { structuring } \\
\text { deconstructing }\end{array}$ & $\begin{array}{l}\text { checking } \\
\text { monitoring } \\
\text { detecting } \\
\text { testing } \\
\text { critiquing } \\
\text { judging } \\
\text { reflecting }\end{array}$ & $\begin{array}{c}\text { generating } \\
\text { hypothesizing } \\
\text { assembling } \\
\text { designing } \\
\text { constructing }\end{array}$ \\
\hline \multicolumn{6}{|c|}{ Bloom's digital taxonomy } \\
\hline $\begin{array}{c}\text { naming } \\
\text { locating } \\
\text { finding } \\
\text { bullet pointing } \\
\text { highlighting } \\
\text { bookmarking } \\
\text { favouriting } \\
\text { searching } \\
\text { googling }\end{array}$ & $\begin{array}{l}\text { advanced } \\
\text { searches } \\
\text { blog } \\
\text { journaling } \\
\text { twittering } \\
\text { tagging } \\
\text { commenting } \\
\text { annotating } \\
\text { subscribing }\end{array}$ & $\begin{array}{l}\text { running } \\
\text { loading } \\
\text { operating } \\
\text { hacking } \\
\text { uploading } \\
\text { sharing } \\
\text { editing }\end{array}$ & $\begin{array}{l}\text { linking } \\
\text { validating } \\
\text { reverse } \\
\text { engineering } \\
\text { cracking }\end{array}$ & $\begin{array}{c}\text { blog } \\
\text { commenting } \\
\text { reviewing } \\
\text { posting } \\
\text { moderating } \\
\text { collaborating } \\
\text { networking } \\
\text { refactoring }\end{array}$ & $\begin{array}{l}\text { programming } \\
\text { filming } \\
\text { animating } \\
\text { video blogging } \\
\text { mixing } \\
\text { wiki-ing } \\
\text { publishing } \\
\text { videocasting } \\
\text { podcasting } \\
\text { directing } \\
\text { broadcasting }\end{array}$ \\
\hline
\end{tabular}

*collaboration: negotiating, debating, net meeting, skyping, video conferencing, networking, chatting, emailing, texting, instant messaging

Among six categories from BDT, it is crucial to notice the newly attached element of collaboration to the category of evaluation. Taking the approach of connectivism (Kop \& Hill, 2008) in collaboration, digital learning helps learners to easily link to the updated information and knowledge to share ideas through various online learning performances such as net meeting, posting, commenting, video conferencing, podcasting, and instant messaging. These activities also could develop their creative and critical knowledge as well as contribute to their learning autonomy.

Concerning establishing thinking skills through learning, BDT suggests interrelations of three different processes of learning, as shown in Figure 1. It demonstrates that the cognitive domains of "Remembering and Understanding" are 
acquired in the phase of "Knowledge acquisition". In this phase, learners grasp the concrete knowledge and identify the information. On the basis of this phase, learners then deepen their knowledge by applying and analyzing their acquired knowledge in practical contexts. In the phase of "Knowledge Creation", learners evaluate and create knowledge through collaborating, networking, constructing, and publishing via various digital formats, such as video conferencing, blogging, and wiki-ing. Given that digitalized learning platforms and methods have unique features of flexibility and accessibility, learners at any level of cognitive dimension could establish collective intelligence. This is because the scaffolded learning task could be accompanied by higher taxonomic levels through various networks of associates.

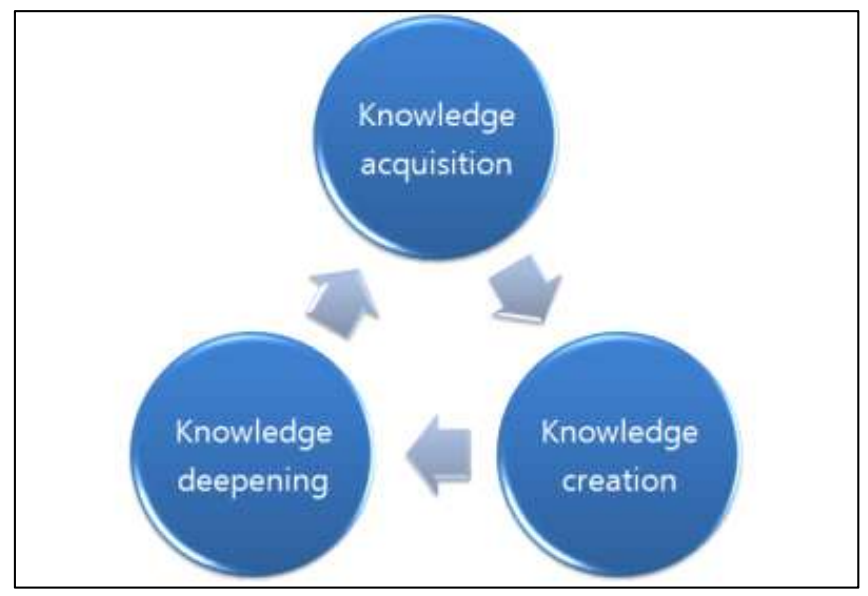

Figure 1. Learning cycle of Bloom's digital taxonomy

\subsection{Dictogloss}

This dictogloss is a cooperative learning method in which learners reconstruct the listening text (Wajnryb \& Maley, 1990) in a group activity. It is derived from traditional dictation which is modified to promote learners' own productive language use to convey the gist of the listening text. The general procedure of dictogloss is demonstrated in Figure 2.

In this procedure, each learner listens and takes notes individually at the first and the second stage, then works in group to rewrite (or paraphrase) the listening text by discussing the structure of sentences and accurate grammar usage to maintain the meaning of the original text. 
A short text is read at normal speed for 2 or 3 times.

At first, learners do not take notes but concentrate on the overall meaning of the listening text.

\section{$\downarrow$}

In the second and third time of a teacher's reading the text aloud at normal speed, learners take notes with key words and phrases.

$\downarrow$

Working in small groups of 2 4, learners reconstruct the text in full sentences from their shared note-taking.

$\downarrow$

Each group produces its own reconstructured version concerning grammatical accuracy and textual cohesion but not replicating the original text.

$\downarrow$

The various versions generated from each group, are then analyzed and compared. Learners refine their own texts in light of shared scrutiny and discussion.

Figure 2. General procedure of dictogloss

This activity is effective in promoting metalinguistic competence, which deals with strategic knowledge for performing cognitive tasks, as well as multiple language skills: listening, writing, and reading skills. It also stimulates practical use of linguistic knowledge such as vocabulary, parts of speech, sentence structure, and collocation (Kim, 2008; Kim \& Kim, 2019; Lee, 2011; Maeda, 2018; Snoder \& Reynolds, 2019; Wajnryb \& Maley, 1990).

As dictogloss encourages learners to display knowledge of linguistic elements and organizational structure to keep the main topic of the text by collaborating with each other, it offers greater insight into learners' thinking process by real-time observation. Unlike solely product-based modes of assessment implemented in traditional tasks, dictogloss enables teachers to assess learners' production with understanding of the process-based complement (Jacobs \& Small, 2003). In other words, teachers are able to monitor and assess multiple language abilities with various types of production which are displayed in each stage of dictogloss, such as note-taking (individual production) and reproducing sentences (cooperative production) based on the notes (Vasiljevic, 2010; Maeda, 2018). 


\subsection{Dictogloss in cognitive approach}

In the cognitive approach, Vasiljevic (2010) states that language learners' cognitive domain could be stimulated in the process of reconstructing the text. He defines the process of performing dictogloss as cognitive conflict or complex cognitive process which is usually generated in the process of comparing and analyzing the reconstructed text with the original. In this cognitive conflict, learners recognize the deficient elements of their language ability when they compare their output with their peers' output or the original text. Swain and Lapkin (1995) depict the recognition of the deficiencies during the cognitive process as excavation of new linguistic knowledge as well as facilitation of acquired knowledge.

Concerning the different cognitive levels of each learner, it is crucial to consider the quality of the learning process which could help learners to develop lower-order thinking skills and higher-order thinking skills. Taking the relevance of the cognitive process and dictogloss into consideration, this study will analyze how variation of dictogloss facilitates language learners' cognitive domain in the digitalized learning context based on Bloom's digitalized taxonomy.

\section{Methodology}

\subsection{Participants}

Sixty-four first-year university students participated in this study who were from two classes (32 participants in each class) with a similar English proficiency (Their mean score of a mock TOEIC test was 385). Their majors were all different but all within the college of engineering. The dictogloss classes were conducted three times in a listening and reading class in a general English course during 15 week-curriculum in the first semester of 2021. It was operated in two manners which were a synchronous class and a pre-recorded video class every other week. All the classes were carried out in a web-based online learning context due to the Covid 19 pandemic.

\subsection{Course description}

Three types of dictogloss variants were employed in the class. In the first and 
the third dictogloss activities, 9 to 10 groups of 3 to 4 students (Class 1 and Class 2 , respectively) cooperatively performed the task with each group being assigned a different dictogloss. The listening text for the first and the second dictogloss were identically used for both classes, but the third was different.

In the first dictogloss activity, which was taken from Lim's study (2021), students read several reading passages as a preparatory stage of dictogloss to gain some background knowledge about the listening text before watching the video clip. Then the procedure of dictogloss was briefly instructed. After instruction, a short video clip was played without subtitles first at normal speed. After they watched the video clip and got a glimpse of the main idea of the listening text, they were asked to do note-taking individually. Concerning the length, the narration speed, and the complexity of description in the video clip, subtitles were presented in the second and the third time of note-taking phases. This was designed to lessen cognitive overload (or working memory) for students and help them to extract the key information and to recreate the listening text. In order to stimulate further cognitive learning, the dictogloss activities were modified into two versions; dictogloss summaries and dictogloss opinion (See Appendix 1 and 2 for the listening text and the production of a student's dictogloss opinion).

The second dictogloss class was performed in an asynchronous manner in a whole class activity except the note-taking portion which was still carried out individually. It was designed for those who feel uncomfortable to engage in group discussion and prefer to do reconstruction activities alone (Lim, 2021). In Synchronous class, such as Zoom, students individually took notes while they listened to the text that were read by the lecturer several times (See Appendix 3 for the original listening text). Then each student submitted their individually completed draft of the reconstruction of the listening text to a lecturer by mail in order to create collaborative work and at the same time to avoid any students freeloading (to track their reconstructing process). The collected drafts were then uploaded in the online bulletin board to share with a whole class (See Figure 3). Then each student referenced others' drafts to analyze, edit, and reconstruct their original drafts and complete the re-writing task.

In the third dictogloss activity, students were instructed in groups to expand their reconstructed passage by adding more descriptions or personal experiences. In this dictogloss activity, each class listened to a different listening text, which had different sentence structures and different levels of difficulty to see the different patterns of the cognitive process. In other words, class 2 listened to the listening script which 
contained learned grammatical points in the text, while class 1 listened to the text with more complicated sentence structures and with more specific information about the unit topic (See Table 3).

Table 2. Examples of collected students' drafts for the second dictogloss task

\begin{tabular}{|c|c|c|c|}
\hline $\begin{array}{l}\text { She was looking for a } \\
\text { key. and there was a key } \\
\text { on the kitchen table, but } \\
\text { it was too high }\end{array}$ & $\begin{array}{c}\text { she climbed up the } \\
\text { window to find the key, } \\
\text { but it was very high. So } \\
\text { I called my tall son. }\end{array}$ & $\begin{array}{l}\text { she couldn't find a key. } \\
\text { and she try to climb tree } \\
\text { but it is too high so she } \\
\text { couldn't climb the tree. } \\
\text { she hear the noise of her } \\
\text { son in room }\end{array}$ & $\begin{array}{l}\text { She is looking for her } \\
\text { key. She have seen a key } \\
\text { at kitchen table }\end{array}$ \\
\hline $\begin{array}{l}\text { She left her key on the } \\
\text { kitchen table. Her son } \\
\text { took care of it. }\end{array}$ & $\begin{array}{l}\text { mother coudn't get in } \\
\text { and she coudn't climb } \\
\text { tree because tree is tall. } \\
\text { fortunatly her son come } \\
\text { home. }\end{array}$ & $\begin{array}{c}\text { she couldn't find key. } \\
\text { kitchen table, it was too } \\
\text { high }\end{array}$ & $\begin{array}{l}\text { she couldn't climb tree } \\
\text { because tree was too. she } \\
\text { didn't have handphone. } \\
\text { she listened noise at } \\
\text { sitting room. she's son is } \\
\text { in home. }\end{array}$ \\
\hline
\end{tabular}

Table 3. Listening text for the third dictogloss task

\begin{tabular}{|c|c|c|}
\hline & Class 1 & Class 2 \\
\hline $\begin{array}{l}\text { Listening } \\
\text { text }\end{array}$ & $\begin{array}{l}\text { FIFA, the international football } \\
\text { association has increasingly put } \\
\text { emphasis on fair play. For instance, a } \\
\text { record number of yellow cards were } \\
\text { given out during a FIFA World Cup } \\
\text { championship match in } 2010 \text {. The } \\
\text { Netherlands received nine (including } \\
\text { two on the same player resulting in a } \\
\text { red) and Spain received five. (Excerpted } \\
\text { from culture notes in teachers' book) }\end{array}$ & $\begin{array}{l}\text { Last night, Camford United won the } \\
\text { football league championship. The team } \\
\text { has won the championship four times } \\
\text { now-the first time was in 1986. In their } \\
\text { final game yesterday, Bryan Riggs } \\
\text { scored the winning goal. Riggs has been } \\
\text { with the team since he left school. } \\
\text { (Excerpted from Essential Grammar in } \\
\text { Use, Supplementary Exercises) }\end{array}$ \\
\hline
\end{tabular}

Given that dictogloss could improve learners' paraphrasing skills based on note-takings from spoken input and rebuilding the text (Jacobs \& Small, 2003; Park, 2013), the present study took various modified versions and analyzed them by BDT.

\subsection{Data collection \& data analysis}

The data for this study were collected from March to May 2021, which was composed of students' submitted assignments of dictogloss production and lecturer's reflective notes taken from each dictogloss class. The reflective notes were taken after 
observing the process of students' engagement in online discussion to obtain in-depth understanding of the students' process-based leaning production. The data from students' assignments were codified and analyzed according to the 6 categories proposed by Bloom's digital taxonomy, which are composed of remembering, understanding, applying, analyzing, evaluating, and creating with digitalized action verbs (or key verbs). Table 4 presents the action verbs associated with the cognitive process and the relevant examples for dictogloss in students' production which were codified and then frequencies and percentages of the codes were calculated. Lecturer's reflective notes were taken as a reference to determine learning actions to certain key verbs of the cognitive categories.

Table 4. Categories of cognitive processes and examples

\begin{tabular}{|c|c|c|}
\hline Categories & Key verbs & Examples \\
\hline Remembering & $\begin{array}{l}\text { Recognizing, naming, } \\
\text { identifying, social networking, } \\
\text { googling, searching, etc. }\end{array}$ & $\begin{array}{l}\text { Taking notes, using word processing, highlighting } \\
\text { keywords, making list }\end{array}$ \\
\hline Understanding & $\begin{array}{l}\text { Summarizing, paraphrasing, } \\
\text { classifying, comparing, } \\
\text { tagging, etc. }\end{array}$ & $\begin{array}{l}\text { Explaining the main idea and details to } \\
\text { construct collaborative text, using graphics, } \\
\text { tagging (members' comments), threaded } \\
\text { discussions }\end{array}$ \\
\hline Applying & $\begin{array}{l}\text { Implementing, uploading, } \\
\text { sharing, editing, etc. }\end{array}$ & $\begin{array}{l}\text { Implementing collaborative dictogloss task by } \\
\text { discussing and sharing the concepts of the text } \\
\text { through video conferencing, using technique- } \\
\text { based strategies (i.e. uploading files or typing } \\
\text { note-taking words in the chating box) }\end{array}$ \\
\hline Analyzing & $\begin{array}{l}\text { Mashing, linking, integrating, } \\
\text { structuring, etc. }\end{array}$ & $\begin{array}{l}\text { Determing the overall structure of the writing } \\
\text { text, distinguishing between components, } \\
\text { selecting words and phrases for reconstructing } \\
\text { with accurate use of linguistic form and } \\
\text { meaning }\end{array}$ \\
\hline Evaluating & $\begin{array}{l}\text { Monitoring(blog/vlog), } \\
\text { commenting, posting, } \\
\text { collaborating, networking, } \\
\text { reflecting, etc. }\end{array}$ & $\begin{array}{l}\text { Judging and moderating the drafts, reflective } \\
\text { practice by using blogs or social networking } \\
\text { (i.e. Kakao Talk or discussion board) }\end{array}$ \\
\hline Creating & $\begin{array}{l}\text { Constructing, producing, } \\
\text { mixing, etc. }\end{array}$ & $\begin{array}{l}\text { Creating new ideas or perspective by combining } \\
\text { ideas or adding critical opinions or extra details } \\
\text { based on the collaboration by using online tools } \\
\text { writing reconstructured text of the listening text } \\
\text { by integrating members re-writing parts }\end{array}$ \\
\hline
\end{tabular}


To obtain validity and reliability of the analysis, the data were analyzed by three different researchers; one as an intra-coder who is the researcher, and the others as inter-coders, who were English education experts with more than 7 years of teaching experience and relevant academic degrees a Masters degree and a Doctoral degree in English education. The coded data showed good inter-rater reliability with 0.83 in Cohen's Kappa.

\section{Results \& Discussion}

Findings of the study demonstrated that learners used various dimensions of thinking skills during their performance in dictogloss tasks as aforementioned in the section of literature review (Anderson \& Krathwohl, 2001; Churches, 2008; Cooke \& Leise, 2018; Jacobs \& Small, 2003). Figure 3 showed the overall use of the cognitive categories of Bloom's digital taxonomy taken from three different dictogloss variations. It showed that the categories of remembering, understanding, and applying are predominantly used in dictogloss with more than $90 \%$, while those of analyzing and creating with less than 50\% (See Table 5). This could indicate that the learning action and process with the lower-thinking skills were activated as basic resources to perform higher-thinking skills in dictogloss.

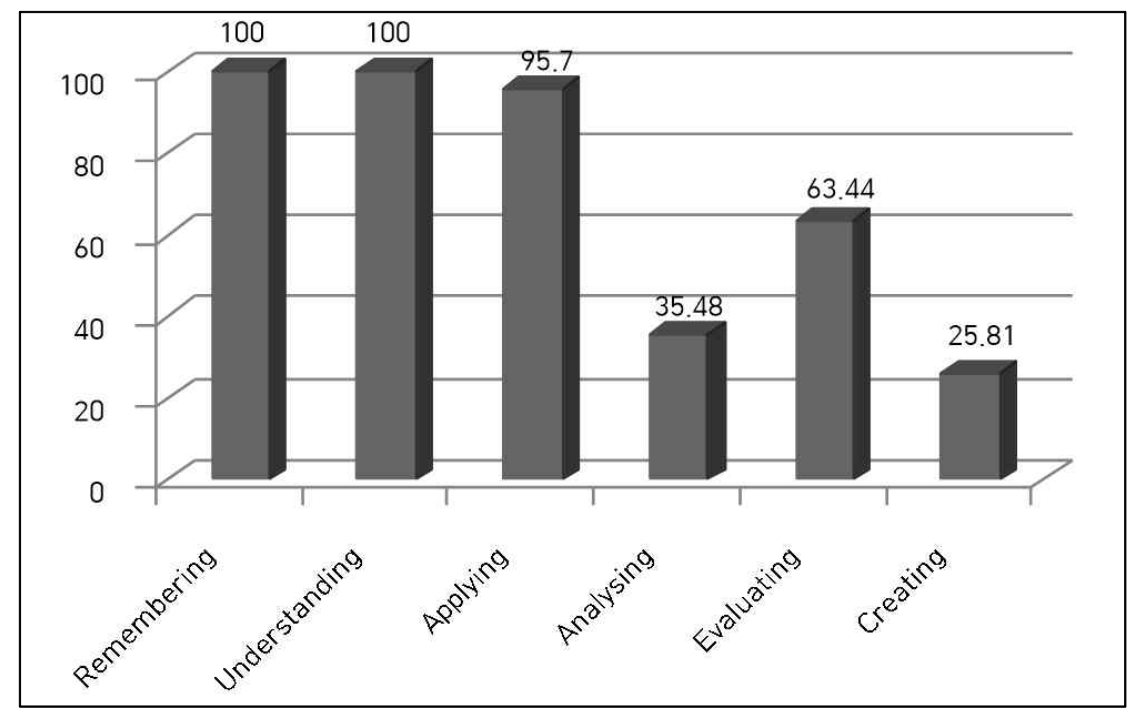

Figure 3. Overall percentage of the cognitive domain by dictogloss 
Table 5. Total data of three dictogloss tasks

\begin{tabular}{ccccccc}
\hline & Remembering & Understanding & Applying & Analyzing & Evaluating & Creating \\
\hline \hline Frequency & 93 & 93 & 89 & 33 & 59 & 24 \\
\hline Rate & $100.00 \%$ & $100.00 \%$ & $95.70 \%$ & $35.48 \%$ & $63.44 \%$ & $25.81 \%$ \\
\hline
\end{tabular}

* Each number in 'Frequency' represents the total number of data taken from three dictogloss tasks.

In addition, the result of higher rates in the evaluating category compared to the analyzing category could account for the effective use of networking in collaborative performance to review, detect, and monitor the output.

Even though three dictogloss tasks were collaboratively carried out in synchronous and asynchronous learning modes, the learning process of each dictogloss covered different cognitive domains. Unlike the overall similar results of remembering and understanding categories presented in Figure 3, Table 6 demonstrated that the other categories of the cognitive process were differently utilized according to the process of each dictogloss (See Appendix 7 to 9 for the raw data of each dictogloss).

Table 6. The frequency and percentage of the cognitive domain performed by dictogloss

\begin{tabular}{|c|c|c|c|c|c|c|c|}
\hline & & Remembering & Understanding & Applying & Analyzing & Evaluating & Creating \\
\hline $\begin{array}{l}\mathrm{T} \\
\mathrm{a} \\
\mathrm{s}\end{array}$ & Class 1 & $\begin{array}{c}100 \% \\
(10 / 10)\end{array}$ & $\begin{array}{c}100 \% \\
(10 / 10)\end{array}$ & $\begin{array}{c}70 \% \\
(7 / 10)\end{array}$ & $\begin{array}{c}60 \% \\
(6 / 10)\end{array}$ & $\begin{array}{c}80 \% \\
(8 / 10)\end{array}$ & $\begin{array}{c}80 \% \\
(8 / 10)\end{array}$ \\
\hline $\begin{array}{l}\mathrm{k} \\
1\end{array}$ & Class 2 & $\begin{array}{l}100 \% \\
(9 / 9)\end{array}$ & $\begin{array}{l}100 \% \\
(9 / 9)\end{array}$ & $\begin{array}{c}88.89 \% \\
(8 / 9)\end{array}$ & $\begin{array}{c}66.67 \% \\
(6 / 9)\end{array}$ & $\begin{array}{c}77.78 \% \\
(7 / 9)\end{array}$ & $\begin{array}{c}77.78 \% \\
(7 / 9)\end{array}$ \\
\hline $\begin{array}{l}\mathrm{T} \\
\mathrm{a} \\
\mathrm{s}\end{array}$ & Class 1 & $\begin{array}{c}100 \% \\
(32 / 32)\end{array}$ & $\begin{array}{c}100 \% \\
(32 / 32)\end{array}$ & $\begin{array}{c}100 \% \\
(32 / 32)\end{array}$ & $\begin{array}{c}15.63 \% \\
(5 / 32)\end{array}$ & $\begin{array}{c}50 \% \\
(16 / 32)\end{array}$ & $0.00 \%$ \\
\hline $\begin{array}{l}\mathrm{k} \\
2\end{array}$ & Class 2 & $\begin{array}{c}100 \% \\
(32 / 32)\end{array}$ & $\begin{array}{c}100 \% \\
(32 / 32)\end{array}$ & $\begin{array}{c}100 \% \\
(32 / 32)\end{array}$ & $\begin{array}{c}25.00 \% \\
(8 / 32)\end{array}$ & $\begin{array}{c}60 \% \\
(19 / 32)\end{array}$ & $0.00 \%$ \\
\hline $\begin{array}{l}\mathrm{T} \\
\mathrm{a} \\
\mathrm{s}\end{array}$ & Class 1 & $\begin{array}{c}100 \% \\
(10 / 10)\end{array}$ & $\begin{array}{c}100 \% \\
(10 / 10)\end{array}$ & $\begin{array}{c}100 \% \\
(10 / 10)\end{array}$ & $\begin{array}{c}60 \% \\
(6 / 10)\end{array}$ & $\begin{array}{c}80 \% \\
(8 / 10)\end{array}$ & $\begin{array}{c}80 \% \\
(8 / 10)\end{array}$ \\
\hline $\begin{array}{l}\mathrm{k} \\
3\end{array}$ & Class 2 & $\begin{array}{l}100 \% \\
(9 / 9)\end{array}$ & $\begin{array}{l}100 \% \\
(9 / 9)\end{array}$ & $\begin{array}{l}100 \% \\
(9 / 9)\end{array}$ & $\begin{array}{l}100 \% \\
(9 / 9)\end{array}$ & $\begin{array}{l}100 \% \\
(9 / 9)\end{array}$ & $\begin{array}{l}100 \% \\
(9 / 9)\end{array}$ \\
\hline
\end{tabular}

As mentioned earlier in this study, Task 1 was carried out by integrating reading text and listening text to perform reconstructing the text by summarizing and giving opinions with the given questions based on the content of the text. In this task, learners' cooperative productions exhibited high rates in the category of evaluating and creating ( $80 \%$ for both categories) followed by the applying (70\%) and analysing 
(60\%). Task 3 which was conducted as elaboration dictogloss also demonstrated a similar distribution of percentage as Task 1. Specifically, the result of class 2 with simpler sentence structures and pre-learned grammar knowledge showed higher cognitive progress. This could be assumed that simpler structures and pre-learned linguistic knowledge in the text would be effective for EFL learners to facilitate multi cognitive processes.

In Task 2, the listening text with the note-taking words and phrases taken from Zoom was paraphased in individual work by taking reference from the online discussion board. Since this task was conducted in an asynchronous learning mode by uploading their drafts of reconstructed text, the result showed a distinctively different pattern of using the cognitive categories. Students independently use the given information to create and revise reconstructed text which can generate considerable individual difference in the process of analyzing. Thus the result might turn out with less proportion in the analyzing category compared to evaluating category. This could indicate that the elements of analyzing would be more effective in a synchronous cooperative learning actions.

Through these different patterns of the cognitive domain, such as analyzing, evaluating, and creating, between task 1, 3 and task 2, could be assumed that higher cognitive skills could be more utilized by prompt interactive collaboration process, such as using video conferencing and group discussion through breakout rooms in Zoom.

The overall findings from three various types of dictogloss conformed to Churches' study (2018) that cooperative learning through networking association promoted various categories of the cognitive process of learning: from lower thinking skills to higher thinking skills. This was consistent with Bloom's cognitive taxonomy which indicated that "learning activities often involve both lower order and higher order thinking skills as well as a mix of concrete and abstract knowledge" (Anderson \& Krathwohl, 2001, pp. 4-5).

\section{Conclusion}

This study is conducted as an empirical research to investigate how students' cognitive domain could be facilitated by implementing dictogloss in the context of digital learning mode. Their thinking skills are observed and analyzed by their production on the basis of collaborative restructuring of the listening text in various 
processes, such as adding opinions, extra descriptions, and summarizing. The findings could be summarized as follows. First, learners actively engage in collaborative learning by exchanging notes or ideas through chatting box or using breakout rooms, which enable them to immediately receive others' reactions and monitor the process of learning. Second, the result of dictogloss conducted in a synchronous learning mode (i.e. Zoom with breakout rooms and chatting box) outperforms that of dictogloss carried out in an asynchronous mode. It can be indicated that prompt interaction is effective to develop the cognitive skills through digitalized collaborative learning context. In short, learners tend to use more higher-cognitive skills in a synchronous learning mode, such as analyzing and correcting their reconstructed production which has missing elements or incorrect language use by discussing with others. The findings of the research is aligned with the previous studies (Batstone, 1994; Cooke \& Leise, 2018; Ellis, 1995; Stockwell, 2010) that the collaborative learning in digital-mediated mode promotes collective intelligence which are accompanied with contacting and communicating via network association. In short, within technology-mediated learning context (i.e. synchronous e-learning for immediate interactions), integrative language learning tasks can develop higher cognitive skills as well as the usage of linguistic knowledge in various manners.

Taking pedagogical implications into account based on these advantages of dictogloss, education practitioners can design various types of dictogloss. Dictogloss in diverse digital-mediated learning modes can combine with multi language skills and extend customized learning opportunities with flexible interactions between learners and educationers. For instance, when scaffolding instructions and activities accompanied by asynchronous modes, such as LMS (Learning Management System), online discussion board, personal message, learners at any English proficiency can participate in the dictogloss with more confidence and autonomy.

Despite these positive aspects of dictogloss, however, there are some limitations to this preliminary study. First, except dictogloss 3, groups are not divided into controlled and experimental groups to see the distinctive effect of dictogloss. In addition, in order to see the distinct effect of digitalized dictogloss, on site dictogloss should be comparatively investigated with identical dictogloss variants. Second, statistic analysis is not provided in this study which can provide the correlevance of elements of dictogloss and each category of cognitive process that are conducted in web-based learning modes. Concerning these limitations, the future study should take further in-depth examination with specified conditions. 


\section{References}

Anderson, L. W. \& Krathwohl, D. R. (2001). A taxonomy for learning, teaching, and assessing a revision of Bloom's Taxonomy. New York: Longman Publishing.

Baek, S. H., \& Lee. J. H. (2012). The effects of English proficiency and text difficulty on collaborative dialogue during dictogloss. Korean Journal of Applied Linguistics, 28(1), 87-114.

Batstone, R. (1994). Grammar. Oxford: Oxford University Press.

Churches, A. (2008). Bloom's digital taxonomy. Retrieved from http://burtonslifelearn ing.pbworks.com/f/BloomDigitalTaxonomy2001.pdf (Accessed on May, 21, 2021).

Cooke, S. \& Leis, A. (2018). Dictogloss: Redefining dictation exercises in the EFL classroom. In 5th International Conference on Business and Industrial Research (ICBIR) (pp. 526-529). IEEE.

Díaz, A. R. (2013). Developing critical languaculture pedagogies in higher education: Theory and practice. Multilingual Matters.

Ellis, R. (1995). Interpretation tasks for grammar teaching. TESOL Quarterly, 29(1):87-105.

Jacobs, G. \& Small, J. (2003). Combining dictogloss and cooperative learning to promote language learning. The Reading Matrix, 3(1), 1-15.

Kim, Y. (2008). The contribution of collaborative and individual tasks to the acquisition of L2 vocabulary. The Modern Lanugage Journal, 92, 114-130.

Kim, J. \& Kim, Y. (2019). The effects of input/output enhanced instructions on vocabulary and grammar gains in blended learning. Linguistic Research, 36 (Special Edition), 107-122.

Kop, R. \& Hill, A. (2008). "Connectivism: learning theory of the furture or vestige of the past?" International Review of Research in Open and Distance Learning, 9(3), 1-13.

Lee, H. S. (2011). Analyzing the effects of English news listening lessons using dictogloss at a university level. Foreign Languages Education, 18(1), 225-251.

Lim, Y. (2021). The effects of revised dictogloss in synchronous online learning and the perspective of Korean university students. Journal of Research in Curriculum \& Instruction, 25(3), 261-270.

Maeda, M. (2018). The potential advantage of dictogloss as an assessment tool for EFL learners' proficiency. Annual Review of English Language Education in Japan, 29, 33-48.

Oh, Y. \& Min, C. (2011). The effects of dictogloss using cooperative learning on the improvement of English writing abilities. Modern English Education, 12(4), 237-257.

Park, O. H. (2013). The effect of dictogloss on university students' listening and writing ability. Journal of Learner-Centered Curriculum and Instruction, 13(5), 453-479.

Snoder, P. \& Reynolds, B. L. (2019). How dictogloss can facilitate collocation learning in ELT. ELT Journal, 73(1), 41-50.

Stockwell, M. A. (2010). Literature review: The theoretical underpinning of dictogloss/ Michael A. Stockwell. Journal of Sugiyama Jogakuen University.-Humanities, 41, 109-119.

Swain, M., \& Lapkin, S. (1995). Problems in output and the cognitive processes theygenerate: a step towards second language learning. Applied Linguistics, 16, 371-391. 
Swain, M. (2006). Languaging, agency and collaboration in advanced second language profi ciency. Advanced language learning: The contribution of Halliday and Vygotsky, 95-108.

Vasiljevic, Z. (2010). Dictogloss as an interactive method of teaching listening comprehension to L2 learners. English Language Teaching, 3(1), 41-52.

Wajnryb, R. \& Maley, A. (1990). Grammar dictation (Vol. 3). Oxford University Press.

Yilmaz, Y. (2011). Task effects on focus on form in synchronous computer-mediated communication. The Modern Language Journal, 95(1), 115-132.

Zeng, G. (2017). Collaborative dialogue in synchronous computer-mediated communication and face-to-face communication. ReCALL, 29(3), 257-275.

\section{Youngshin Lim}

\section{Lecturer}

Department of General Education

Kongju National University

1223-24 Cheonan-daero, Seobuk-gu, Chungnam 31080, Korea

E-mail: 1y224@kongju.ac.kr

Received: July 7, 2021

Revised version received: September 29, 2021

Accepted: December 6, 2021

\section{Appendix}

\section{Listening text for dictogloss opinion in <Dictogloss $1>$ (Excerpted from 'Urban} Life' in Youtube)

About one third of the world's population web sites such as worldometer have been set up to
show a continuous readout of world population growth. Hongkong is one of the most densely
populated areas on earth. Its small area is packed with over seven million people. Urban areas
provide large numbers of jobs. Cities can be amazing places. The denser populations can support
institutions that rural areas cannot, such as great libraries and museums, universities and cultural
centers for the performing arts with a mix of very old and very new buildings.




\section{Example of students' dictogloss opinion in <Dictogloss $1>$}

Responding to the text (asking learners' opinion): In what ways can living in the city be bad for you?

Answers from each member of a group: First. the city is expensive place to live.(S5) There is a lot of noise and a lack of fresh air.(S6) And pollution problem is also serious and harmful to health.(S7) City is prone to stress because of traffic congestion, easy transmission of disease, and constant competition.(S8) Finally, unlike the country, the city doesn't have active exchanges with local inhabitants and neighbors.(S9)

\section{Examples of students' note taking in <Dictogloss 1>}

S5: traffic congestion, noise, pollution, Quiet time, night sky can be an exhilarating, denser population support institutions

S6: fresh air, natural view, neighbor, swap vegetables, migration, breakfast together, pollution, safe family life

S7: dangerous, metropolitan areas, migration, pollution, culture activities, education, many jobs, cultural centres, transportation hubs

S8: more culture activities, many facilities, high salaries, the architecture can be fascinating, little fresh air, a lot of noise, skip breakfast, good job
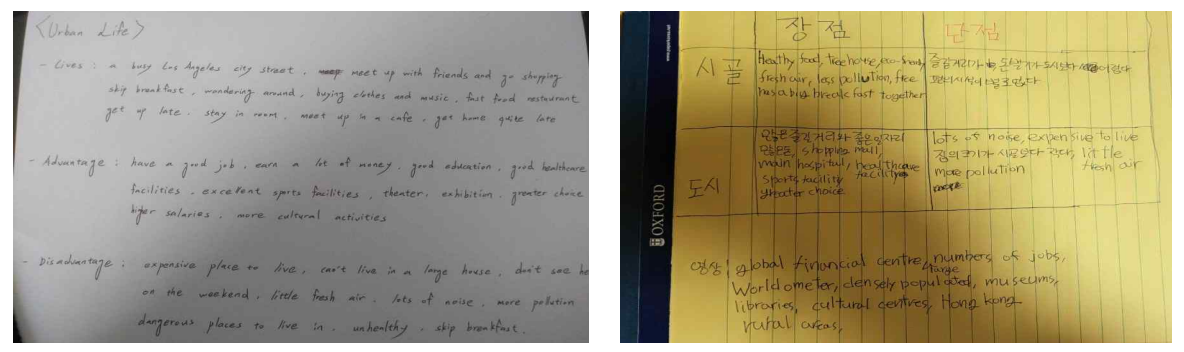

4. Listening text for asynchronous dictogloss in <Dictogloss 2> (Excerpted from Essential Grammar in Use, Supplementary Exercises)

'Oh dear! Where's her key? She couldn't find it. Oh look! I could see it on the kitchen table. Since she couldn't get in, she tried to climb the tree to the window on the first floor. But she couldn't climb it because it was too high. Furthermore, she couldn't phone for help because she didn't have her smartphone with her. Meanwhile, she could heard some noise coming from the sitting room. Fortunately, her son, Peter was at home. What a relief!!! 


\section{An example of dictogloss elaboration for $<$ Dictogloss $3>$ (Class 1 )}

FIFA, The international football association has increasingly put emphasis on fair play. For intance, A record number of yellow cards for given out. [Yellow cards will be received for fouling in the game. If you receive more than one card, you will be sent off and you will not be able to participate in the next match.(S21)] During on FIFA World Cup Championship Match in 2010, The Netherlands received 9, Including the same player receiving two and becoming red, and Spain received 5. [In the case of South Korea, South Korea played Uruguay in the round of 16. In that match, South Korea received three yellow cards and Uruguay did not receive one.(S22)] [Another example of fair play is Mattia Agnes, who is still 17 years old, who was honored for her quick-thinking courage in providing critical first aid to unconscious opponents after a field crash and was awarded the FIFA Fair Play Award.(S23)]

\section{An example of dictogloss elaboration for $<$ Dictogloss $3>$ (Class 2 )}

Last night, there was a exciting final game which held in stadium. A large of audience gathered at the stadium for the match. One of the teams participating in the game is Campot United. Brian Briggs scored a winning goal in yesterday's final game. The match ended with his goal and all his teammates rushed to him for a ceremony. Brian Briggs graduated from school and he has been with team since the day he left school. By winning yesterday, team called Campot United won the championship a total of four so far. To be more specific, the team won their first victory in 1986 and yesterday was the last.

\section{Raw data from Dictogloss 1}

\begin{tabular}{ccccccc}
\hline Group & Remembering & Understanding & Applying & Analyzing & Evaluating & Creating \\
\hline \hline A1 & 1 & 1 & 1 & 0 & 1 & 1 \\
A2 & 1 & 1 & 1 & 1 & 1 & 1 \\
A3 & 1 & 1 & 1 & 1 & 1 & 1 \\
A4 & 1 & 1 & 1 & 1 & 1 & 1 \\
A5 & 1 & 1 & 1 & 1 & 1 & 1 \\
A6 & 1 & 1 & 1 & 1 & 1 & 1 \\
A7 & 1 & 1 & 0 & 0 & 0 & 0 \\
A8 & 1 & 1 & 0 & 0 & 0 & 0 \\
A9 & 1 & 1 & 1 & 1 & 1 & 1 \\
A10 & 1 & 1 & 0 & 0 & 1 & 1 \\
Total & 10 & 10 & 7 & 6 & 8 & 8 \\
Rate & $100 \%$ & $100 \%$ & $70 \%$ & $60 \%$ & $80 \%$ & $80 \%$ \\
\hline
\end{tabular}




\section{Continued}

\begin{tabular}{ccccccc}
\hline Group & Remembering & Understanding & Applying & Analyzing & Evaluating & Creating \\
\hline \hline B1 & 1 & 1 & 0 & 0 & 1 & 1 \\
B2 & 1 & 1 & 1 & 1 & 1 & 1 \\
B3 & 1 & 1 & 1 & 0 & 0 & 0 \\
B4 & 1 & 1 & 1 & 1 & 1 & 1 \\
B5 & 1 & 1 & 1 & 1 & 1 & 1 \\
B6 & 1 & 1 & 1 & 1 & 1 & 1 \\
B7 & 1 & 1 & 1 & 1 & 1 & 1 \\
B8 & 1 & 1 & 1 & 0 & 0 & 0 \\
B9 & 1 & 1 & 1 & 1 & 1 & 1 \\
Total & 9 & 9 & 8 & 6 & 7 & 7 \\
Rate & $100 \%$ & $100 \%$ & $88.89 \%$ & $66.67 \%$ & $77.78 \%$ & $77.78 \%$ \\
\hline
\end{tabular}

* A1 stands for Group 1 and B1 stands for Group 2, respectively.

8. Raw data from Dictogloss 2

\begin{tabular}{ccccccc}
\hline Students & Remembering & Understanding & Applying & Analyzing & Evaluating & Creating \\
\hline \hline AS1 & 1 & 1 & 1 & 0 & 1 & 0 \\
AS2 & 1 & 1 & 1 & 0 & 1 & 0 \\
AS3 & 1 & 1 & 1 & 0 & 1 & 0 \\
AS4 & 1 & 1 & 1 & 0 & 1 & 0 \\
AS5 & 1 & 1 & 1 & 0 & 1 & 0 \\
AS6 & 1 & 1 & 1 & 0 & 1 & 0 \\
AS7 & 1 & 1 & 1 & 0 & 1 & 0 \\
AS8 & 1 & 1 & 1 & 0 & 1 & 0 \\
AS9 & 1 & 1 & 1 & 0 & 1 & 0 \\
AS10 & 1 & 1 & 1 & 1 & 1 & 0 \\
AS11 & 1 & 1 & 1 & 0 & 1 & 0 \\
AS12 & 1 & 1 & 1 & 0 & 1 & 0 \\
AS13 & 1 & 1 & 1 & 1 & 1 & 0 \\
AS14 & 1 & 1 & 1 & 0 & 1 & 0 \\
\hline & & 1 & & & & \\
\hline
\end{tabular}


8. Continued

\begin{tabular}{|c|c|c|c|c|c|c|}
\hline Students & Remembering & Understanding & Applying & Analyzing & Evaluating & Creating \\
\hline AS15 & 1 & 1 & 1 & 0 & 1 & 0 \\
\hline AS16 & 1 & 1 & 1 & 0 & 1 & 0 \\
\hline AS17 & 1 & 1 & 1 & 0 & 1 & 0 \\
\hline AS18 & 1 & 1 & 1 & 1 & 1 & 0 \\
\hline AS19 & 1 & 1 & 1 & 0 & 1 & 0 \\
\hline AS20 & 1 & 1 & 1 & 0 & 1 & 0 \\
\hline AS21 & 1 & 1 & 1 & 1 & 1 & 0 \\
\hline AS22 & 1 & 1 & 1 & 0 & 1 & 0 \\
\hline AS23 & 1 & 1 & 1 & 0 & 1 & 0 \\
\hline AS24 & 1 & 1 & 1 & 0 & 1 & 0 \\
\hline AS25 & 1 & 1 & 1 & 0 & 1 & 0 \\
\hline AS26 & 1 & 1 & 1 & 1 & 1 & 0 \\
\hline AS27 & 1 & 1 & 1 & 0 & 1 & 0 \\
\hline AS28 & 1 & 1 & 1 & 0 & 1 & 0 \\
\hline AS29 & 1 & 1 & 1 & 0 & 1 & 0 \\
\hline AS30 & 1 & 1 & 1 & 0 & 1 & 0 \\
\hline AS31 & 1 & 1 & 1 & 0 & 1 & 0 \\
\hline AS32 & 1 & 1 & 1 & 0 & 1 & 0 \\
\hline Total & 32 & 32 & 32 & 5 & 16 & 0 \\
\hline Rate & $100 \%$ & $100 \%$ & $100 \%$ & $15.63 \%$ & $50 \%$ & $0 \%$ \\
\hline Students & Remembering & Understanding & Applying & Analyzing & Evaluating & Creating \\
\hline BS1 & 1 & 1 & 1 & 1 & 1 & 0 \\
\hline BS2 & 1 & 1 & 1 & 0 & 1 & 0 \\
\hline BS3 & 1 & 1 & 1 & 0 & 1 & 0 \\
\hline BS4 & 1 & 1 & 1 & 0 & 1 & 0 \\
\hline BS5 & 1 & 1 & 1 & 0 & 1 & 0 \\
\hline BS6 & 1 & 1 & 1 & 0 & 1 & 0 \\
\hline BS7 & 1 & 1 & 1 & 0 & 1 & 0 \\
\hline BS8 & 1 & 1 & 1 & 1 & 1 & 0 \\
\hline
\end{tabular}


8. Continued

\begin{tabular}{|c|c|c|c|c|c|c|}
\hline Students & Remembering & Understanding & Applying & Analyzing & Evaluating & Creating \\
\hline BS9 & 1 & 1 & 1 & 0 & 1 & 0 \\
\hline BS10 & 1 & 1 & 1 & 0 & 1 & 0 \\
\hline BS11 & 1 & 1 & 1 & 1 & 1 & 0 \\
\hline BS12 & 1 & 1 & 1 & 0 & 1 & 0 \\
\hline BS13 & 1 & 1 & 1 & 0 & 1 & 0 \\
\hline BS14 & 1 & 1 & 1 & 0 & 1 & 0 \\
\hline BS15 & 1 & 1 & 1 & 0 & 1 & 0 \\
\hline BS16 & 1 & 1 & 1 & 1 & 1 & 0 \\
\hline BS17 & 1 & 1 & 1 & 0 & 1 & 0 \\
\hline BS18 & 1 & 1 & 1 & 0 & 1 & 0 \\
\hline BS19 & 1 & 1 & 1 & 1 & 1 & 0 \\
\hline BS20 & 1 & 1 & 1 & 0 & 1 & 0 \\
\hline BS21 & 1 & 1 & 1 & 0 & 1 & 0 \\
\hline BS22 & 1 & 1 & 1 & 0 & 1 & 0 \\
\hline BS23 & 1 & 1 & 1 & 1 & 1 & 0 \\
\hline BS24 & 1 & 1 & 1 & 0 & 1 & 0 \\
\hline BS25 & 1 & 1 & 1 & 0 & 1 & 0 \\
\hline BS26 & 1 & 1 & 1 & 1 & 1 & 0 \\
\hline BS27 & 1 & 1 & 1 & 0 & 1 & 0 \\
\hline BS28 & 1 & 1 & 1 & 0 & 1 & 0 \\
\hline BS29 & 1 & 1 & 1 & 1 & 1 & 0 \\
\hline BS30 & 1 & 1 & 1 & 0 & 1 & 0 \\
\hline BS31 & 1 & 1 & 1 & 0 & 1 & 0 \\
\hline BS32 & 1 & 1 & 1 & 0 & 1 & 0 \\
\hline Total & 32 & 32 & 32 & 8 & 19 & 0 \\
\hline Rate & $100 \%$ & $100 \%$ & $100 \%$ & $25 \%$ & $59.38 \%$ & $0 \%$ \\
\hline
\end{tabular}

* AS1 represents for S1 in Group 1, BS1 represents for S1 in Group 2, respectively. 
9. Raw data from Dictogloss 3

\begin{tabular}{|c|c|c|c|c|c|c|}
\hline Group & Remembering & Understanding & Applying & Analyzing & Evaluating & Creating \\
\hline A1 & 1 & 1 & 1 & 0 & 0 & 0 \\
\hline $\mathrm{A} 2$ & 1 & 1 & 1 & 1 & 1 & 1 \\
\hline A3 & 1 & 1 & 1 & 1 & 1 & 1 \\
\hline A4 & 1 & 1 & 1 & 1 & 1 & 1 \\
\hline A5 & 1 & 1 & 1 & 0 & 1 & 1 \\
\hline A6 & 1 & 1 & 1 & 1 & 1 & 1 \\
\hline A7 & 1 & 1 & 1 & 1 & 0 & 0 \\
\hline A8 & 1 & 1 & 1 & 0 & 1 & 1 \\
\hline A9 & 1 & 1 & 1 & 1 & 1 & 1 \\
\hline A10 & 1 & 1 & 1 & 0 & 1 & 1 \\
\hline Total & 10 & 10 & 10 & 6 & 8 & 8 \\
\hline Rate & $100 \%$ & $100 \%$ & $100 \%$ & $60 \%$ & $80 \%$ & $80 \%$ \\
\hline Group & Remembering & Understanding & Applying & Analyzing & Evaluating & Creating \\
\hline B1 & 1 & 1 & 1 & 1 & 1 & 1 \\
\hline B2 & 1 & 1 & 1 & 1 & 1 & 1 \\
\hline B3 & 1 & 1 & 1 & 1 & 1 & 1 \\
\hline B4 & 1 & 1 & 1 & 1 & 1 & 1 \\
\hline B5 & 1 & 1 & 1 & 1 & 1 & 1 \\
\hline B6 & 1 & 1 & 1 & 1 & 1 & 1 \\
\hline B7 & 1 & 1 & 1 & 1 & 1 & 1 \\
\hline B8 & 1 & 1 & 1 & 1 & 1 & 1 \\
\hline B9 & 1 & 1 & 1 & 1 & 1 & 1 \\
\hline Total & 9 & 9 & 9 & 9 & 9 & 9 \\
\hline Rate & $100 \%$ & $100 \%$ & $100 \%$ & $100 \%$ & $100 \%$ & $100 \%$ \\
\hline
\end{tabular}

